Homeless at home in East Durham

Katy Bennett

Dept. of Geography

University of Leicester

Bennett Building

University Road

Leicester

LE1 7RH

kjb33@le.ac.uk 


\section{Homeless at home in East Durham}

\section{Abstract}

This paper contributes to research on homelessness and home focussing on the experiences of young, working class women living in privately rented or social housing in the former coalfields of East Durham in north east England. Although the women had a place to live they rarely felt 'at home' because they lived in the most deprived areas of East Durham or too far away from family and friends or in substandard accommodation. The women were denied the 'normative values of home' that should be, as Iris Marion Young (1997) argued, accessible to everyone. Whilst most of the women were on a waiting list for social housing, home was experienced in the emotional space of imagining and hoping to move house whilst living with the frustration of not moving. They often felt homeless. The paper sets the young women's experiences of home(lessness) against a changing housing policy context.

Keywords: Home, homelessness, class, gender, housing, ethnographic

\section{Introduction}

Leah: $\quad$ 'You live out of boxes. Ridiculous. I mean from leaving me Mum's

House into a Housing Association house and then moved to my Aunt's and then I moved to Butlins, then I moved back down to me Nan's and then I moved up here and we were living with his Dad and then we went into the housing...into the em, homeless thing, into the house we're in now and I'm sick and tired of living in a box and suitcase. All we had was a suitcase when we came up here. Frigging horrible. Absolutely horrible. Hated it.'

Donna: I was living with me nanna and (pause) I had really bad post natal depression because she was just trying to take over my life basically and I couldn't cope with it and still they wouldn't give us anything. And me nanna threatened to chuck us out and they says well you can go in a refuge. And I says I don't want to, I've just had a baby. I don't want to be stuck in a refuge by meself. I says I'll find me own' 
Leah and Donna live in the former coalfields of East Durham in the north east of England, a place badly hit by the pit closures of the 1980s and 1990s with Easington District the $7^{\text {th }}$ most deprived district in England. The source of their accommodation problems is a shortage of good quality social housing. Both women provide some introductory insight into how physically and emotionally exhausting it is to be in need of social housing and subject to systems of allocation that, in the first instance, try to prevent homelessness. Donna was threatened with living in a homeless refuge when she could no longer cope with living with her grandmother whilst caring for her young baby. Both women were also subject to a housing allocation system that denied them choice and eroded their ability to plan for the future. When Leah moved into her house it had no flooring. She also lives in a neighbourhood that she wants to escape and is on a waiting list again for a new house.

The aim of this paper is to contribute to research on homelessness and how individuals can feel homeless at home. Although, as Leah and Donna demonstrate, some of the women have experienced homelessness in the conventional sense (living in a hostel for the homeless) or experienced homelessness described by academics as 'hidden' (staying with a relative), they all had a place of their own at the time of the research. The women, however, often felt homeless at home and this paper aims to explore and explain their experience. It begins with a focus on homelessness and home. Key here is the porosity of home and the idea of 'possession' that emerges from Miller's (2001b) research which helps to explain why the women sometimes felt haunted by where they lived. Following the focus on homelessness and home the paper explores some of the reasons why there is a shortage of social housing in East Durham, especially as this used to be an area of 'low demand' regarding housing. 
Based on ethnographic research, it introduces a political economy that intersected the home life of the women important to this paper affecting their insecurity regarding housing and their experiences of homelessness. The second part of the paper then explores the women's experiences of homelessness and home, particularly the intersection of these, using Young's (1997) normative values of home to frame discussion.

\section{Homelessness and Home}

\section{Homeless at Home}

There is now broad consensus that homelessness does not simply comprise those who apply to local authorities for homelessness assistance (the 'statutory homeless') and people sleeping out in the open ('rough sleepers'), but also households living in temporary or inadequate accommodation (see, for example, Klodawsky 2006 and Department for Communities and Local Government, previously ODPM, 2003). For some time the scale, scope and experience of homelessness have been the subject of considerable research with academics critical of policies, definitions, representations, and statistics that masked its extent. Such policies include, for example, the 1996 Housing Act which made it no longer a duty for local authorities to provide permanent accommodation for those accepted as homeless (Cloke et al 2000a; Malos and Hague 1997). To circumvent this policy change Cloke at al (2000a) showed how local authorities often identified households in homeless situations as being in 'housing need' rather than homeless, providing them with a route into more permanent, secure accommodation (Cloke et al 2000a). Representations of homelessness also mask the extent of homelessness, identifying the issue with rough sleepers in city centres, leaving experiences of homelessness particularly 'hidden' in 
rural areas. (Cloke et al 2000b, 2000c, 2001, 2003; Robinson with Coward 2003). Finally, the experiences of particular groups, including women and young people, are hidden because they are more likely to pursue informal strategies to secure a roof over their heads, through, for example, staying with friends or, in the case of women, attaching themselves to 'housed men' (Klodawsky 2006; Robinson with Coward 2003). Such people are rarely recorded in statistics of homelessness.

Research on the 'hidden' homeless has focussed on people who have found an often temporary and unsatisfactory housing solution and are off the radar of the authorities. This paper is keen to develop a further dimension of hidden homelessness understanding how people can feel 'homeless at home' (see also Blunt and Dowling 2006; Kellett and Moore 2004; Wardhaugh 1999). This happens when a person has somewhere to live, even a place they consider home. Homelessness at home might be experienced when struggling to pay bills and visited by debt collectors (Robinson 2002), when living with abuse and domestic violence (Malos and Hague 1997) or when subject to the imposition of heterosexual norms and assumptions (Valentine 1993).

For this paper, however, feeling 'homeless at home' extends beyond the impact of those physically present at home, such as visitors or cohabitants. Less obvious 'others' affect home too, demonstrating the porosity of home (Sibley 1995; Varley 2008). Others have a presence through both the material and immaterial. These others can affect pleasurable, and as the paper will explore, less than pleasurable experiences of home. Pleasurable experiences of home can be affected by photographs, for example, that imbue home with familiar others (Rose 2003; Tolia-Kelly 2004a, 2004b). 
Mothers and grandmothers might live elsewhere, but affect home life (Mitchell and Green 2002; Wheelock and Jones 2002). I am influenced here by feminist accounts of households, which although not directly concerned with home, convey ideas that might be extended into this discussion. Important to such work is how households comprise more than those who live together to include others that affect (often through their work activities and consumption practices) its economy and coping strategies (Wheelock and Oughton 1996; Wheelock et al 2003; Wheelock and Jones 2002). Homes similarly embody significant others, like mothers and grandparents, who affect the material, imaginative and affective experience of home.

Others can have a less pleasurable, more sinister effect, causing people to feel 'homeless at home'. The idea of possession - not simply a matter of ownership, but also the spectral presence of 'others' in home - is important to this paper and understanding homelessness at home. In his edited collection Home Possessions, Miller (2001a, 2001b) undermined home as an expressive genre, writing how 'quite often we are not the agents that create the material environment of our representation' (Miller 2001b: 112). To illustrate this, he wrote about how residents of local authority owned apartments in North London felt 'haunted and depressed' (Miller 2001b: 113) by 'the council', a presence that became objectified in the building itself:

'A sense of bitterness about their own lack of agency exacerbates the sense that one is oppressed by a home that is anything but an expression of one's agency. Rather it is a constant reminder that power lies elsewhere. I do not think it is too much to claim that most of the people on this estate feel haunted, although they do not need to anthropomorphize a ghost since the figure of the 
council provides a clear repository for their fears and frustrations' (Miller 2001b: 119).

The idea of possession captures not only the lack of agency and sense of surveillance experienced by the young women important to this paper but also the extent to which (the attitudes of) powerful others (including social workers, housing officials, government policy makers, media) haunted them. The ignominy of 'punitive surveillance' (Peel, 2003: 94) experienced by residents of social housing and living in areas described as 'disadvantaged' has been the subject of other research, including the work of Mark Peel (2003), whose book The Lowest Rung provides an intimate account of 'impoverished Australians' living in an increasingly divided Australian society. Such surveillance amounted to living 'in the zoo' (2003: 25) with respondents learning to play for their various audiences. Miller's (2001b) research and reference to 'possession' conveys this sense of surveillance, but also captures the lingering, sometimes intangible, often damaging presence of others in the lives of council tenants. Possession suggests that these others are internalised and, as Miller (2000b) describes above, projected onto 'the council'.

Apart from briefly referring to the way in which people who could not afford to own their home felt stigmatised in a society in thrall of home ownership, Miller (2001b) did not explore in detail residents' sense of possession, 'the council' and why they felt haunted and depressed. Other research and writing provide pathways of potential insight. A good starting point is burgeoning work on class, and class relations in particular, that has broadened its intellectual scope to include issues of identity and culture (see this journal 2008: McDowell 2008; Stenning 2008; Strangleman 2008; 
Wills 2008; also Bottero 2004; Lawler 2005; Lawler 2008). Of particular interest here is research on powerful discourses - through the media and government rhetoric that identify working class people in ways that vilify them, whilst normalising the middle class (McDowell 2006). Steph Lawler (2002), for example, compared the treatment in broadsheet newspapers of working and middle class women angered by the potential threat of paedophiles living nearby. Working class women living on an estate in Portsmouth were subjected to aggressive media scorn regarding their performances and mothering practices that the middle class women in an affluent suburb of London escaped. In a similar vein, Gurney (1999a, 1999b) has written about discourses, practices and power relations that normalise home-ownership so that:

'Owners are normal and normalised and live in homes, renters are neither and live in houses. The normalising discourse here has created a tenure of prejudice' (Gurney 1999a: 58)

Vilification and prejudice are not eased by policies designed to tackle, for example, the processes that lead to social exclusion that often have a moral undertone in their discursive treatment of lone mothers and deprived neighbourhoods as individuals are blamed for their failure to surmount socio-structural dimensions of inequality (Lawler 2005; McDowell 2006; Watt and Jacobs 2000). Such discursive vilification of the working class and social housing tenants through the state and other media inevitably seeps into the lives and home-making practices of those living in social housing, affecting, as Miller (2001) describes, how home is experienced (see also Mitchell and Green 2002; Mitchell 2004; Skeggs 1998). 
Underpinning homelessness is often a sense of ideal home. Ideal home can be unsettling as it is held in tension with lived experience of home, contributing to feelings of homelessness when situations are less than ideal, sometimes much worse. Significant to this paper is not just home, but an imaginary ideal home. Ideal homes are culturally and historically specific and usually unreachable - often existing in other places and times. They seep into homely aspirations, desires and expectations through public discourse in the media, popular culture and public policy (Blunt and Dowling 2006; Mallett 2004). Ideal homes weave through television programmes concerned with buying dream houses and lifestyle magazines advertising interior design, decoration and the necessary accoutrements of ideal living. They also figure in the selling of real estate supported by government policy regarding, for example, home ownership (Mallett 2004). In recent times, British representations of ideal home often cocoon heterosexual, middle class, white nuclear families in detached, owner occupied suburban houses (Blunt and Dowling 2006). This ideal home is exclusive, designed around the (impossible) separation of, for example, inside from outside, private from public and safety from danger. It seems to remove those who inhabit it from public scrutiny and surveillance, providing them with some semblance of control over their lives whilst nestling them in a blanket of security under which they can recuperate and regenerate (Dovey 1985; Relph 1976).

It is precisely this sense of home that has been the object of feminist critique and attempts to challenge and unsettle home (see Darke 1994; Young 1997). Home is strongly associated with the denial of female subjectivity as women service the needs and desires of men so that they might feel at home in a place that they probably own. Ideal home is underpinned by patriarchal family relations. The privileging of home 
along lines of race and class has also been the subject of feminist critique. Home is constructed:

'in opposition to the uncertainties and dangers of streets and foreign territories where various riff-raff hang out in less than homey conditions' (Young 1997: 157)

Yet despite being the subject of such critique, home, desire for home, the seduction of an ideal home affects individuals and the society they shape. The women central to this paper longed for home and the normative values of home that Young (1997) argued should 'be thought of as minimally accessible to everyone'. These include safety - a place to feel secure; individuation - somewhere to routinely perform the basic activities of life; privacy - a sense of ownership of one's home; and preservation - the right to safeguard the meaningful objects and aspects of home important to memories and stories of oneself.

Democratising home in the way that Young (1997) suggests sits, at first glance, perhaps a little uncomfortably with more recent research on a sense of home that is capacious, stretching across space and time, absorbing memories, fantasies and other places (Blunt and Dowling 2006; Tolia-Kelly 2004a, 2004b). Home is understood as 'more than a site in which we live' (Blunt and Dowling 2006: 2), evoking place(s), spaces, memories, imagined futures, emotions, subjectivities, identities, power relations and is shaped by practices, routines, rules, mundane acts and extraordinary events. Blunt and Dowling (2006) describe home as a 'spatial imaginary': 
' a set of intersecting and variable ideas and feelings, which are related to context, and which construct places, extend across spaces and scales, and connect places' (Blunt and Dowling 2006: 2)

Young (1997) though makes some reference to not only the material but also the imaginative and affective geographies of home, referring, for example, to feelings of security and meaningful objects that evoke memories (of people and places) important to sense of self and home. Young (1997) also recognises that home is important to identity as 'a site for constituting and performing self-hood' (Jacobs and Smith 2008: 515), providing space to be/do oneself, perhaps contrary to (although still influenced by) the designs of others. Various research, often influenced by Miller (1988), has explored how the home making practices of residents have attempted to mollify the restrictive constraints of powerful authorities and their housing designs (see Clarke 2001; Ureta 2007). The research showed how home could be a space to resist their identification by powerful authorities. For bell hooks (1990), home provided space to develop strength in relation to (racist) others and to nurture senses of selves alternative to their identification through oppressive others and exploitative relations. These accounts of home and significance for identity sit comfortably with Young's (1997) argument about democratising home.

The women who are the focus of this paper were denied Young's (1997) normative values of home which left them feeling homeless much of the time. They were consumed by a sense that things could be better, that they could do better for their children. A desire for the security and sanctity of an ideal home seeped into their aspirations for home, but stopped short at the consumerist excess visions of ideal 
home that dominate the media. Their housing biographies were punctuated by relatively frequent moves, yet they simultaneously felt stuck in a place as home was produced and experienced in the space of imagining and fantasising about moving home. Given the potential immanence of moving house, the women were sometimes reluctant to invest too much time or too many resources into home improvement. They often felt confined to a locality and a housing system marked by shortage and low quality. The following section explores the practices and policies that have contributed to a shortage of decent social housing in East Durham.

\section{Housing and Welfare Concerns}

This section explores some of the reasons behind a shortage of social housing in East Durham and difficulties accessing it. It also considers the discursive damage done to women that affects their welfare more generally. A critical starting point is the lack of funding to improve the amount and quality of social housing available to prospective tenants. East Durham's mining heritage meant that much of the housing in pit villages and towns was built and owned by mining companies and then, with nationalisation of the coalmining industry, the National Coal Board (NCB) (see Figure 1). However when the mining industry went into decline and pits in the region began to close, the NCB began to sell its housing stock, initially offering properties to tenants, local authorities and housing associations, before advertising them on the open market (Beynon et al 2000). A lack of Housing Investment Programme (HIP) funding meant that Easington District Council ${ }^{\mathrm{i}}$ was in a weak position to buy unwanted houses from the NCB allowing 'absentee' landlords to buy swathes of properties cheaply. The problems that this has caused tenants, residents and the local authority have been immense (Beynon et al 2000). More recently, tranches of central 
funding aimed at housing focus on the needs of urban locations, leaving their hinterlands comparatively bereft of financial support. Housing renewal funding, for example, has been allocated to urban cores, such as NewcastleGateshead, through CLG's Housing Market Renewal Pathfinder Programme, leaving sub-regional housing markets under-funded (DCC 2007).

There has also been a distinct policy shift affecting housing, especially in areas described as 'low demand' with an oversupply of sub-standard terraced housing, vacant properties and pockets of dereliction. An emphasis on neighbourhood renewal with its focus on tackling the causes of social exclusion through community development has been replaced by a focus on housing market renewal, which is a 'bricks and mortar' led attempt to restructure low income neighbourhoods (Cameron 2006). This policy shift means that parts of villages and towns in East Durham, such as Easington Colliery, Dawdon and Parkside, have been targeted for demolition accompanied by (proposed) largely private housing developments designed to attract and retain a professional and skilled workforce needed to support regional spatial strategies and economic regeneration agenda (see Figures 2, 3 and 4). Although it is stipulated that $20 \%$ of private housing developments should be reserved for the social sector, the power of private developers means that local residents are lucky if this happens (Commission for Rural Communities 2006). The consequence of this policy shift is that:

'during the period since the end of the 1990s homelessness appears to have risen most rapidly precisely in those regions where housing market renewal policies are concentrated (Cameron 2006: 13). 
Cameron (2006) states that in the four year period between 1999-2000 and 2003-4, while statutory homelessness in England increased by 30\%, in the North East region the increase was $73 \%$. Growing economic and housing security for some is linked to increasing insecurity and misery for others (Chouinard 2006). Deepening the problem of homelessness and a shortage of social housing is Right to Buy (RTB), which was first introduced in 1979. Although the current government has ratcheted down RTB, reducing available discounts in many areas and increasing the minimum time before houses can be sold on, RTB still allows tenants to purchase their homes (Harris 2008). In April 2006 Easington District Council owned 9278 dwellings (22.1\% of total dwellings in Easington District), compared with 12,297 dwellings (29.9\% of total dwellings) in April 2001 (http://www.neighbourhood.statistics.gov.uk). Some of this, but not much in Easington District, has been offset by an increase in dwellings owned by Registered Social Landlords which have increased from $4.1 \%$ to $4.3 \%$ of total dwellings over the same period (http://www.neighbourhood.statistics.gov.uk).

As Leah and Donna revealed at the start of the paper, individuals are often made to feel powerless by the system of allocating social housing. A shortage of social housing means that not everyone on low incomes and needing the security of tenure offered by the social sector qualifies for social housing in a needs-based allocation system (Arthurson and Jacobs 2004; Fitzpatrick et al 2007). It also means, as Donna showed, local authority intervention to minimise levels of homelessness and those needing social housing (DCC 2007). For people who do qualify for social housing, there has been little choice. In a 'take it or leave it' housing allocation model, prospective tenants who refuse the house on offer forfeit their housing priority if they are homeless and are one step closer towards not being allocated a house (because 
only so many can be refused) (Fitzpatrick et al 2007; Pawson and Kintrea 2002). Such a coercive system tends to concentrate those with greatest housing need in the most deprived and least popular areas (Holmans et al 2007). It also means that they are probably housed in sub-standard accommodation. In 2006/7 75\% of Local Authority owned properties in Easington District were defined as non-decent dwellings, failing to meet criteria that included being in a decent state of repair, having 'reasonably modern facilities and services and a reasonable degree of thermal comfort' (GONE 2007: 35). Properties owned by private landlords, the only alternative for those who fail to qualify for social housing, are often in no better, and often in much worse, condition.

Weakening support for the welfare of working class women, especially lone mothers, are powerful discourses that objectify and vilify them through various media and government rhetoric discussed earlier. Discursive damage done to working class women, particularly lone mothers, associates them with an underclass reinforced by a benefit structure encouraging a culture of dependency and young women to get pregnant to access council housing (Levitas et al 2006). Despite there being no evidence to support the claim that women get pregnant to access housing or social security benefits, policies have weakened support of lone parents (Phoenix 1991). Under the Conservative Governments of the 1980s and early 1990s, for example, RTB reduced the amount of local authority owned housing available to the homeless and low paid and the 1996 Housing Act withdrew the statutory link between homelessness and a lifeline to permanent housing (Malos and Hague 1997). Although New Labour, since 1997, has been concerned with tackling the processes that lead to social exclusion, policies often have a moral undertone in their treatment of lone 
mothers through, for example, the New Deal for Lone Parents (see Levitas et al 2006; see also Helm 2008).

\section{Leah, Louise, Sarah, Becky, Jane, Cara, Mel and Donna ${ }^{\text {ii }}$}

The paper is based on ethnographic research, which included in-depth group work with eight women aged between 16 and 24 (see Figure 5). This method aimed to capture the emotional consequences of the intersection of political economy and home. The women were selected on the basis of their age as part of a broader research project concerned with the relationship between identities and regeneration for women living in the former coalfields of East Durham. I did not know any of the women prior to the research and the group came together with help from a contact at Easington District Council. The group met three times in the Autumn of 2006. Each meeting lasted for approximately three hours.

Figure 5: Home life of women

\begin{tabular}{|c|c|c|c|}
\hline Name & $\begin{array}{l}\text { Children living at } \\
\text { home }\end{array}$ & $\begin{array}{l}\text { Additional } \\
\text { adults living at } \\
\text { home full time }\end{array}$ & $\begin{array}{l}\text { Length of time in current } \\
\text { accommodation }\end{array}$ \\
\hline Leah & $\begin{array}{l}\text { Two children } \\
\text { (aged } 1 \text { and } \\
\text { 7weeks) }\end{array}$ & Husband & $\begin{array}{l}\text { Lived in current Local } \\
\text { Authority (LA) } \\
\text { accommodation for less than } \\
2 \text { years }\end{array}$ \\
\hline Louise & $\begin{array}{l}\text { Two children } \\
\text { (aged } 5 \text { and } 2 \text { ) }\end{array}$ & Partner & $\begin{array}{l}\text { Moved into privately rented } \\
\text { accommodation at the time of }\end{array}$ \\
\hline
\end{tabular}




\begin{tabular}{|c|c|c|c|}
\hline & & & the research \\
\hline Sarah & One child (aged 1) & & $\begin{array}{l}\text { Lived in current LA owned } \\
\text { accommodation for } 1 \text { year }\end{array}$ \\
\hline Becky & One child (aged 4) & & $\begin{array}{l}\text { Lived in current Housing } \\
\text { Association (HA) } \\
\text { accommodation for } 2 \text { years }\end{array}$ \\
\hline Jane & $\begin{array}{l}\text { Two children } \\
\text { (aged } 3 \text { and } 1 \text { ) }\end{array}$ & & $\begin{array}{l}\text { Lived in current LA owned } \\
\text { accommodation for } 5 \text { months }\end{array}$ \\
\hline Cara & $\begin{array}{l}\text { Three children } \\
\text { (aged 3,2 and 1) }\end{array}$ & Mother & $\begin{array}{l}\text { Lived in current LA } \\
\text { accommodation for less than } \\
1 \text { year }\end{array}$ \\
\hline Mel & One child (aged 2) & & $\begin{array}{l}\text { Lived in current LA owned } \\
\text { accommodation for } 2 \text { years. }\end{array}$ \\
\hline Donna & One child (aged 2) & & $\begin{array}{l}\text { Lived in current LA owned } \\
\text { accommodation for less than } \\
2 \text { years. }\end{array}$ \\
\hline
\end{tabular}

Figure 1 very briefly introduces each woman and with whom she lives. The amount of time that the women have lived in their current accommodation indicates the extent of the women's forced mobility. Whilst many have moved house often, they also feel simultaneously confined to the locality, stuck in the place where they live. All of the women, apart from Louise, live in social housing. Louise, whilst on a waiting list for social housing, rents a privately owned house. 
Six of the women are lone parents and much of their time is spent looking after their young children. For all the women household incomes were very low, 20\% lower than the following published statistics. For one adult living with at least one child, average household weekly income from April 2006 to March 2007 in Easington District was $£ 193.69$ (CORE 2007). For two adults living with at least one child, average household weekly income was $£ 270.40$ (CORE 2007). Reflecting patterns of statistics, household income for the women of the study who were lone parents was mainly achieved through state benefits. The two women who lived with their partner or husband lived in households that depended upon a mix of waged income and state benefits. Wages in the area are well below average with gross weekly pay for full time workers in Easington District $£ 338$, compared to $£ 448$ for Great Britain (GONE 2007). Managing household finances was a constant, stressful concern in the home lives of the women.

\section{Experiences of Home(lessness)}

In this section I want to contribute to deeper understandings of homelessness through the young women's experiences of home, particularly the tension of feeling homeless at home. Undermining the women's experience of home was, as a previous section established, a lack of decent social housing. This lack meant that the young women central to this research struggled to access social housing, had limited choice regarding where they lived and were sometimes frustrated by a lack of space and the quality of their housing. This section is guided by Young's (1997) normative values of home that should be accessible to all, supported by insights regarding home around ideas of porosity and possession. It needs to be stated from the outset, however, that 
feeling homeless at home is not a constant as there were moments when the women felt at home whilst homeless.

\section{Individuation}

'A person without a home is quite literally deprived of individual existence. However minimal, home is an extension of the person's body, the space that he or she takes up, and performs the basic activities of life - eating, sleeping, bathing, making love.....(T)he individual is not allowed to be if she does not have places to live and to perform the activities of life, with basic routine and security' (Young 1997:162)

The young women left their parental home for many reasons. Underpinning their decision was a desire for 'individual existence' and space where they could nurture their selves and their children without fear of mental or physical abuse. Donna left home to escape parental control and arguments with her brothers; she needed space to be herself. Louise fled a step-father who sexually abused her. Others found a job that provided accommodation or wanted space to nurture their children. Leaving the parental home was not always an easy option. Sarah explained how she felt when she spent her first night alone with her young baby in her recently acquired accommodation:

'I'd stopped at me Mam's two nights when I got out of hospital. I was absolutely petrified. And then I went home and I remember me Mam carrying me bags and I had the bairn and I walked into me house and it was so strange walking in the house with a baby...... And I put her in her, like her, moses basket and I stood there and I was like, what do I do? And I felt lost but then I 
thought, right, the first thing, I need to do some bottles. I was looking around the kitchen like... and I felt like, what do I do? And I was so fidgety....'

Cara was the only woman living with her mother at the time of the research. She had been living many miles away from friends and family in East Durham, but returned 'home' to escape her abusive partner.

The women often chose to set up home independently of men. Like many of the young mothers reported in Phoenix's (1991) study, some of the women had negative attitudes to men and marriage, arguing that men benefited from marriage more than women. Five of the women lived alone with their children, although fathers of children and boyfriends often played a significant role in home life, caring for children. The women, however, controlled when men visited and for how long. There was much laughter when Mel talked of the joy of being able to pretend to her boyfriend when he rang her mobile phone that she was unable to hear him as she switched it off and turned over to go back to sleep. Complicating this 'choice' of independence however was a benefit system that removed from a woman her lone parent status if her boyfriend stayed more than two nights each week (Watson 2004). Living with someone out of work or on a low wage would reduce a woman's benefit entitlement and household income. Sarah, for example, would perhaps live with her boyfriend if the benefit system was structured differently. She revelled in the memory of a recent night when her boyfriend soothed her baby back to sleep, quietly singing to her child whilst he fed her some milk. It is likely that some of the women were 'reluctant rebels' (Wardhaugh 1999: 102), retaining an attachment to an ideal home shaped by living with a partner and children. 
The accommodation that the women rented was often inadequate because it was in a poor state of repair, too small or too far away from friends and family important to home life. Such housing did not accommodate the normative value of individuation described above by Young (1997) - somewhere to nurture self and children. Those in most need of housing had no choice regarding where they lived and were expected to accept the first house they were offered, otherwise as Jane explained, they 'get put back to the bottom of the list'.

Five of the women central to this paper lived in two bedroomed properties, typically in a terraced house with a sitting room and kitchen downstairs and two bedrooms upstairs. The bathroom was either up or downstairs. Louise, who has a partner and two children, moved to a bigger, privately rented property during the research so that one of her children no longer had to share her bedroom with her partner and herself. The remaining women lived in bigger properties, although accommodation was sometimes a squeeze for their growing households. The biggest problems for women were where their house was located and the condition of their accommodation. The women often lived in the most deprived parts of East Durham and sometimes too far away from close friends and family. Mel was happy with her accommodation, but just wished she could wave a wand and move it to another street. None of the women owned a car, so living a mile or two away from a significant person had a big impact on their lives as they coped with public transport and buses permitted to carry only two buggies at one time. It was not uncommon for several buses to pass a woman waiting with her child in a buggy at a bus stop before one with enough space would stop. Family and friends often felt very far away. Others were unhappy with the state 
of their accommodation. For Leah and Louise, substandard housing affected experiences of homelessness.

Given the shortage of decent social housing in places where the women wanted to live, most were on a waiting list for social housing and/or planning to move soon. None of the women had lived in their current accommodation for longer than two years. This forced mobility and search for a decent place to live made it difficult for the women to create a settled, secure sense of home. Despite their transience, however, the women made the best of what they were allocated or had. Most of the women needed to redecorate their newly acquired accommodation, painting walls and making the place home in ways that their limited finances allowed. Friends and relatives sometimes helped, supplying paint left over from decorating their own homes, looking after children so that painting work could be done, or helping with redecoration work themselves. Sometimes it was hard to get the job finished and Leah, in particular, was frustrated by a half painted house (with no flooring).

Local authority owned properties also tend to be let unfurnished and few women could afford to fully furnish their home from the start. Some, such as Sarah, were given 'bits and pieces' from relatives so that most rooms were adequately furnished from the start of the tenancy. Others, such as Mel, were reluctant to accept help from others, especially from her child's paternal grandmother: 'nothing's been given to us, nothing at all'. She was pleased that she had made this decision when she split with the father of her child and was not indebted in anyway to his mother. The women were careful from whom they accepted financial help and loans. To some extent, through their home(lessnesss) the women of this study self-consciously identified 
themselves in ways that contrasted and resisted representations of young mothers as needy and dependent on others that circulate in media and political discourse (Nelson 2002).

Privacy

'Connected with the value of individuation is privacy. A person does not have a place of her own and things of her own if anyone can have access to them. To own a space is to have autonomy over admission to the space and its contents' (Young 1997: 162)

Many of the women felt under surveillance in ways that undermined any sense of privacy. They were familiar with forms requiring personal details and officials with access to their home life. These forms and officials represented authorities that haunted them with their power to (not) help. Absence, as will be shown, was also an important aspect of authorities' haunting of home life. The women were familiar with telling authorities what they wanted to hear and performing in appropriate ways for their various audiences (Peel 2003). They were attuned to the (unnatural) performances or sometimes uncaring attitudes of others which had, as Donna's account of depression at the start of the paper testifies, a less conscious, deeper affect on women and their sense of home(lessness).

The local authority and private landlords made their presence felt in the women's home life through their possession of houses and the bureaucracy that coiled around housing allocation processes (Miller 2001b). Allocation depended on scale of need 
which was calculated through a points based system and prioritised for example, the needs of Sarah, who was in housing need, single and pregnant, over Louise, who was living in privately rented accommodation with her children and a partner in paid work. Home life was subjected to scrutiny as authorities worked out to what extent women were in housing need. The spectral presence of the local authority (and the Arm's Length Management Organisation - East Durham Homes) was simultaneously elusive, whilst haunting and preoccupying home life. The following extract captures the extent to which the council's elusivity consumed home life, with Leah and Sarah explaining the difficulty of tracking down someone who could help Leah with her flooring:

Leah: So you ring up this freephone number and you're talking to someone on the switchboard that ain't got a frigging clue what you're on about and they put you from pillar to post where you can actually.....you used to go to the housing....like the house, walk in, and talk to someone over the counter and it's there, it's done. Now you don't get that, you have to go in

Sarah: Going through the right people. It's like bloody one of them tree things you go down

Leah: It's like that advert with the chickens. I don't mind saying that because me husband's a call centre worker, do you know what I mean, sitting there with chickens and they ain't got a frigging clue what they're on about. "Oh I'll just plug it into the computer and the computer says 
no!". Do you know what I mean? You don't get to see someone face to face. I don't like that at all. Really don't like it

Unable to see anyone the women were confronted with faceless voices who tantalisingly might (not) be able to help. Leah's flooring took two years to fix.

Private landlords similarly haunted home life, their home possession denying women any sense of privacy or ability to invest their selves in their home. Perhaps the greatest concern of Louise, and others who had previously rented in the private sector, was the insecurity of tenure. Home life depended on contracts being renewed on (usually) a six monthly basis and rents not increasing. The women were reluctant to invest their time and energy into their home, through, for example, substantially redecorating rooms, in case landlords decided to profit from their endeavours and not renew their tenancy agreement and/or increase the rent. During the research, as stated earlier, Louise moved from a two to three bedroom house. Initially her new house seemed fine but she quickly discovered that the heating was faulty, making a horrendous banging noise that frightened her when she turned it on. Her landlady wanted Louise to cover some of the repair cost herself, which put Louise and her family in a vulnerable position should the landlady then decide not to renew her contract.

Home life also felt invaded by other authorities, especially those concerned with the women's welfare. It is somewhat ironic that 'the council' through their possession and often elusive management of housing could unsettle people who were then subjected to what sometimes felt like insincere (unnatural) performances of visitors representing 
watchful authorities. The women described their carefully managed responses to the carefully orchestrated performances of health visitors and social workers - 'her face when she walks in she's all like 'Hello'! and you feel, wooooooo....and she's so happy all the time' - and questions - 'Are you alright my love?' - that hovered in the space of their home. Whilst the women felt under surveillance, so too was home life, with one woman upset by the passing comment that her son should only watch ten minutes of television each day. This lack of privacy meant that the women were adept at selfsurveillance, pre-empting judgmental others who might think that they allow their young children to play outside after dark or walk alone to school:

'I mean I do worry about my kids getting older in the area, I really do. I mean I look at my daughter going to school. Now there's about maybes six, seven children in my daughter's class, and me daughter's not even six yet, who walk to school on their own and they're in her class and she keeps saying to me, 'Oh Mam, can I walk down with so and so' and I'm saying 'No Alison' and she's saying 'When can I walk to school on me own?' I say, 'When you've left. When you've left school' But it's like she wants to go out and play with them. Now I know....I know their mams but I don't like them' (Louise).

Although neighbours will be discussed in greater detail with regard to safety, it is worth noting here that neighbours could invade the women's sense of privacy. Although most of the women did not know their neighbours well, rarely inviting them into their home, home life was often invaded by their practices:

'Outside my house at ten o'clock at night you've got them running round, in and out of our garden. And then you go 'Oi, get out of my garden!' (They reply) 'Fuck off!' And they must be only five and you think 'Do you kiss your 
mother with that mouth? You horrible, ignorant little kids'. You just fancy giving them a good slap and....I would never let me kids... They'd probably be allowed outside when they're about fifteen and I trust them. And trust other people around them' (Leah)

Similarly, Becky's home often had to accommodate the practices of her neighbour, a DJ, who played loud music late at night forcing her to move her bedding to the back of her house where she slept on the floor of her child's bedroom.

\section{Preservation}

'Home is the site of construction and reconstruction of one's self. Crucial to that process is the activity of safeguarding the meaningful things in which one sees the stories of one's self embodied, and rituals of remembrance that reiterate those stories' (Young 1997: 164)

The women's desire to move was held in tension with not moving, not knowing when or to where the move would be. Consequently, whilst waiting to move, home ebbed and flowed around the uncertainty, frustration and insecurity of feeling unsettled. This, and limited finances, affected home as a site for the construction and reconstruction of one's self. Not knowing how much money, time and effort to invest in home-making practices caused one of the biggest frustrations. On a waiting list for a new house Leah wanted to buy carpet for her stairs, much needed by two small children crawling up and down them, but did not want to waste money that could be spent on children's coats. Although the women talked about painting rooms to create a sense of home, most were careful not to invest too much time and money into their 
house given that moving might be imminent or, if in rented private housing, tenancies were insecure. Instead, the women invested in objects and media, such as a Sky package, that were important to home and could be easily moved with them. Louise's son, for example had a Thomas the Tank Engine bed canopy which meant that at bedtime he was enshrouded in something familiar whilst living in a new place. No matter how creative the women were, moving and waiting to move house affected home life. Donna, at the start of the paper, described sinking into depression whilst feeling homeless and living with her grandmother and a young baby. Louise described how tearful and 'clingy' her son had been since the move into their new accommodation.

Lack of money also often denied women the value of preservation important to home. Despite the women's forced mobility, debt collection agencies found the women and threatened home life. Most had experience of debt and employed various strategies to deal with it, paying back small sums over a long periods of time, temporarily stopping services, such as the Sky package, important to home life or pawning precious (and meaningful) objects.

To preserve memories of self that stretched back in time, the women reproduced rituals and routines important to their childhood home. Sometimes these memories were painful, but rituals continued so that women could confront and challenge them, affecting home. Louise's memories of Christmas time when she was young were marked by her getting a few second-hand presents which she would not have minded had they not nestled alongside the shiny new objects given to her brother. She remembered lying to school friends about what she had been given because she had 
felt ashamed. In contrast, she made every effort to treat her children equally at Christmas, a particularly poignant and much anticipated moment for all the women in the calendar of home life. Occasionally there was nothing deliberate about the women's actions and mothers' routines from childhood seeped into home life. Leah is worth quoting at length:

Leah: 'Your routine's your routine and you can't go anywhere without it. I can't get up in the morning unless I know what I'm doing because what's the point. You get into a system and nothing gets done. And my Mum hasn't worked for so long I'm scared that if I don't go back to work soon I ain't never gonna go back. I'm gonna get into the system where I go and pick the kids up from school, I come home, I do the housework, maybe sit down, have a cup of coffee, watch the telly like my Mum did, and never have no time for me because she wanted time for herself because oh, you're old enough to look after yourself now, so you don't need me anymore. I'll sit here and do what I want because my Mum never had no time for us. She never used to sit down and do our homework with us. She never read any books. Like now, my boys, I'm like...hold with two hands because I don't want them to feel the way I felt because until....from when I was born, because my sister....there's the same gap between my two boys as there is between me and my sister, but my Mum couldn't cope. My Mum kept my sister and my godparent, which was only my Mum's best friend from school, she was only twenty, took me until I was the age of two. And then my Mum just said I want you. I want her back'

Leah's account of her routine rapidly slid into memories of her mother's routine. Her home soaked up memories of her childhood as she attempted to distance herself from 
her mother's routine, but found herself mirroring some of her mother's practices, even the fact that she had two children close together in age.

\section{Safety}

'Everyone needs a place where they can go to be safe. Ideally, home means a safe place, where one can retreat from the dangers and hassles of collective life' (Young 1997: 161)

Neighbours and neighbourhoods could preoccupy home life, making the women feel unsafe, affecting experiences of homelessness. These experiences, however were interrupted by moments of feeling at home which happened, for example, during children's bath times, fuelled by bubbles, slippery clean babies and the imminence of children's bedtime. In these moments others were pushed to the fringe of home life. Few women knew their neighbours well, not helped by the fact that they had not lived in their neighbourhood long. When they first moved into a new street, they felt watched, particularly by 'the old ones' as they went about their daily business. This made them nervous. Although Cara, gradually got to know most of her neighbours 'watching out for each other - you don't realise it but yous are', others were more wary, perhaps signing for a neighbour's parcel, but having little other contact. Home for Sarah was affected by 'smackheads' living nearby, for others, like Leah and Louise, it was late night noise, music and arguments that they did not dare confront. 'I mean our neighbours in our old house... because every now and again they'd have like friends over and there was arguing, loud music, shouting and everything. And I never dared go and knock on (the door) because you don't know what people are like when they've had a drink. They could be really 
nice when they're sober but then you knock on (the door) and say do you mind turning the music down and they could ... they could hit you. I mean you don't...that's just... I would rather just ignore them and try and drown out the music and just not listen to it basically' (Louise).

Underpinning this reluctance to know neighbours was the real and imagined threat of paedophiles - 'I think these days you're too scared to find out who your next door neighbours are'. Just as the women scouted a new house for danger spots, such as steps, staircases and sockets, they also listened for news and rumours regarding other threats to home life. Conversation was littered with stories and rumours of suspected paedophiles who lived nearby, next to a school and, in one case, on the same street as a woman. Suspected paedophiles were not only men, but also women. Claims were made that Maxine Carr, who famously lied to police to provide the child murderer Ian Huntley with an alibi, had been relocated to the area, living nearby, and, worse still, in disguise. Fear of suspected paedophiles was made worse by one woman's childhood experience of abuse. This fear of paedophiles - and not knowing in what guise they came- meant that some of the women strictly controlled access to their homes and were wary of new neighbours in particular. Most did not feel safe - or at home - in their neighbourhoods.

\section{Conclusion}

This paper has explored the consequences of a shortage of decent social housing for young women living in the former coalfields of East Durham. Once considered a 'low demand' area regarding housing, there is now a shortage of social housing and 
statutory homelessness is on the rise (District of Easington 2008). Although the women all had a roof over their heads at the time of the research, they often felt homeless at home coping with inadequate accommodation and the difficulty of having little choice regarding where they lived.

To explore why the women felt homeless at home, the paper drew upon understandings of home, especially around ideas of porosity and possession. The porous boundaries that shape home allow the policies, practices and attitudes of powerful others to seep into home life affecting home(lessness) as the women felt haunted by (representatives of) authorities with the power to allocate or withdraw housing and affect household and home. Home life was subject to considerable surveillance as the women, for example, responded to systems of housing allocation. This sense of surveillance had far reaching consequences for the women, affecting not simply the self-conscious ways in which they responded to the demands of authorities, but also seeping into the emotional fabric of home life. Developing the idea of possession, the paper attempted to explain why the women felt homeless at home and how they were deeply affected by the practices and policies of others. Home life soaked up inadequate social housing, mechanisms of allocation that denied choice and practices of surveillance making it feel far from homely. In short, the women were often denied the normative values of home that Young (1997) considered 'should be thought of as minimally accessible to everyone'. These include safety - a place to feel secure; individuation - somewhere to routinely perform the basic activities of life; privacy - a sense of ownership of one's home; and preservation - the right to safeguard the meaningful objects and aspects of home important to memories and stories of oneself. As Leah and Donna illustrated at the start of this 
paper, the consequences of homelessness are depression and exhaustion and no place to nurture self and children.

There are policy changes afoot with implications for social housing and the home lives of women central to this paper. Firstly, rule changes recently announced by ministers allow local authorities to retain rent from council housing and receipts from right-to-buy purchasers. This announcement is part of the UK government's intention to introduce a 'devolved system of responsibility and funding' regarding the management of, and long term planning for, council housing (Healey 2009). This has been followed by newspaper headlines announcing ' 139,000 council houses to be built in next decade' and an end to a dramatic decline in council house building that began in the 1950s, when up to 240000 units a year were built (Booth 2009). Some of this excitement is tempered by the fact that much more needs to be done regarding social housing provision, with 5 million people anticipated to be on the waiting list for social housing by 2012 (Healey 2009). Secondly, there is change regarding the way in which social housing is allocated with the government encouraging a shift from a needs based model to one that is choice based, allowing prospective tenants to apply for vacancies in a 'social market' (Fitzpatrick et al 2007). Unless, however, the social housing stock is substantially increased, new housing allocation models will still require a needs based element to house the most vulnerable (see DCC 2008). Thirdly, social housing provision has been affected by the shift in discourse from concerns with low housing demand and abandonment to a focus on housing market renewal, discussed earlier in this paper. (Cameron 2006). Such a policy shift is largely intended to support regeneration agenda designed to retain and attract a professional and skilled workforce to the area. As already suggested, social housing is a relatively marginal 
concern. Finally, the Homelessness Act 2002 placed a duty on every Local Authority to produce a Homeless Strategy and tackle the causes of homelessness. Large sections of Homeless Strategies, however, tend to focus on preventing homelessness through, for example, family mediation, Bond Guarantee schemes and mortgage advice (DCC 2007). They detract from the need to tackle more fully a shortage of good quality social housing.

Although more inclusive understandings of homelessness are in the public and policy domain, there is little evidence to suggest that the decline in social housing - one of its root causes - will be substantially reversed. Since 1977 social housing has fallen from $31 \%$ to $20 \%$ of all housing (CLG 2003). Unless social housing is significantly increased, other housing policies will not help the women central to this research, especially those with no time to wait and in urgent need of accommodation. For these women, home life will continue to be experienced in the emotional space of imagining and hoping to move house whilst living with the frustration of not moving, haunted by waiting lists and inadequate accommodation. They will continue to feel homeless at home.

\section{Acknowledgements}

I would like to thank those who took part in the project, especially the young women central to this paper, Emily Nolan and officers and councillors at Easington District Council. I would also like to thank the anonymous referees and Giles Mohan for their helpful comments on the paper. Final thanks go to the ESRC for funding the research (RES-148-25-0025). 


\section{References}

Arthurson K and Jacobs K (2004) A critique of the concept of social exclusion and its utility for Australian social housing policy. Australian Journal of Social Issues 39 (1): $25-40$

Blunt A and Dowling R (2006) Home. London: Routledge

Beynon H, Hollywood E and Hudson, R (2000) Regenerating Housing. http://www.cardiff.ac.uk/socsi/contactsandpeople/huwbeynon/coalfields-researchprogramme.html (last accessed 1 September 2008)

Booth R (2009) 139000 council houses to be built in next decade The Guardian 07/07/09

Bottero W (2004) Class identities and the identity of class. Sociology 38(5): 9851003.

Cameron (2006) From low demand to rising aspirations: Housing market renewal within regional and neighbourhood regeneration policy. Housing Studies 21 (1): 3-16

Clarke A (2001) The aesthetics of social aspiration. In Eds D Miller Home Possessions: Material culture behind closed doors (pp23-46). Oxford: Berg

Cloke P, Milbourne P and Widdowfield R (2000a) Change but no change: Dealing with homelessness under the 1996 Housing Act. Housing Studies 15 (5): 739-756 
Cloke P, Milbourne P and Widdowfield R (2000b) Homelessness and rurality: 'Out of place' in purified space? Environment and Planning D: Society and Space 18: 715735

Cloke P, Milbourne P and Widdowfield R (2000c) The hidden and emerging spaces of rural homelessness. Environment and Planning A 32:77-90

Cloke P, Milbourne P and Widdowfield R (2001) Homelessness and rurality:

Exploring connections in local spaces in rural England. Sociologia Ruralis 41 (4): $438-453$

Cloke P, Miolbourne P and Widdowfield R (2003) The complex mobilities of homeless people in rural England. Geoforum 34: 21-35

Commission for Rural Communities (2006) Easington Collier - an economically depressed ex-mining town in Durham. Cheltenham: Commission for Rural Communities

Commission for Rural Communities (2008) State of the Countryside Report 2008. Cheltenham: Commission for Rural Communities

Couinard V (2006) On the dialectics of differencing: Disabled women, the state and housing issues. Gender, Place and Culture 13 (4):401-417 
CORE (2007) CORE New Lettings Summary Statistics April 2006-2007: Easington

Area. St.Andrews: University of St. Andrews http://www.core.ac.uk (last accessed 14 September 2008)

Darke J (1994) Women and the meaning of home. In R Gilroy and R Woods (eds) Housing women (pp.11-30). London: Routledge

Department for Communities and Local Government (previously part of ODPM) (2003) More than a roof: a report into tackling homelessness March 2003. London: Department for Communities and Local Government.

District of Easington Council (2008) District of Easington Regeneration Statement. Peterlee: District of Easington Council

Dovey K (1985) Home and homelessness. In I Altman and C M Werner (eds) Home Environments (pp33-64). London: Plenum Press, London

Durham County Council (2007) Making your place in Durham a great place to live: A housing strategy for Durham 2008-2011. Durham: Durham County Council, Durham County Council (2008) County Durham Sub-Regional Homelessness Strategy: Consultation Draft (04/07/08) Durham: Durham County Council

Fitzpatrick S and Pawson H (2007) Welfare safety net or tenure of choice? The dilemma facing social housing policy in England. Housing Studies 22 (2): 163-182 
Government Office for the North East 2007 Local Authority Area Profile: Easington. Newcastle upon Tyne: GONE

Gurney C (1999a) 'We've got friends who live in council houses': Power and resistance in home ownership. In J Hearn and S Roseneil (eds) Consuming cultures: Power and Resistance (pp42-68). Basingstoke: Macmillan Press Ltd

Gurney C (1999b) Lowering the drawbridge: A case study of analogy and metaphor in the social construction of home-ownership. Urban Studies 36 (10): 1705-1722

Harris J (2008) Safe as houses The Guardian 30/9/08 6-11

Healey J (2009) Statement: Housing - Review of Council Housing Finance (30/06/09) www.communities.gov.uk (last accessed 8 July 2009)

Helm T (2008) New job rules 'threaten lone parents'. The Observer 02/11/08

Hickman P and Robinson D (2005) Transforming social housing: Taking stock of new complexities. Housing Studies 21 (2): 157-170

Holmans A Stephens M and Fitzpatrick S (2007) Housing Policy in England since 1975: An introduction to the special issue. Housing Studies 22 (2): 147-162 
Hooks B (1990) Yearning: race, gender and cultural politics. Boston: South End Press

Jacobs JM and Smith SJ (2008) Guest editorial. Living room: rematerialising home. Environment and Planning A 40: 515-519

Kellett P and Moore J (2003) Routes to home: homelessness and homemaking in contrasting societies. Habitat International 27: 123-141.

Klodawsky F (2006) Landscapes on the margins: Gender and homelessness in Canada. Gender, Place and Culture 13(4):365-381

Lawler S (2002) Mobs and monsters: Independent man meets Paulsgrove woman. Feminist Theory 3: 103-113

Lawler S (2005) Introduction: Class, Culture and Identity. Sociology 39 (5): 797-806

Lawler S (2008) Identity: Sociological perspectives. Cambridge: Polity Press,

Levitas R, Head E and Finch N (2006) Lone mothers, poverty and social exclusion.

In C Pantazis, D Gordon and R. Levitas (eds) Poverty and social exclusion in Britain: The millennium survey (pp 405-429). Policy Press

Mallett S (2004) Understanding home: a critical review of the literature. The Sociological Review 52(1): 62-89 
Malos E and Hague G (1997) Women, housing and homelessness and domestic violence. Women's Studies International Forum 20(3): 397-409.

McDowell L (2006) Reconfigurations of gender and class relations: Class differences, class condescension and the changing place of class relations. Antipode 38 (4): $825-850$

McDowell L (2008) Thinking through class and gender in the context of working class lives. Antipode 40(1): 20-24

Miller D (1988) Appropriation of the state on the council estate. Man 23: 353-72

Miller D (2001a) “Behind closed doors”. In D Miller (ed) Home Possessions: Material culture behind closed doors (pp.1-22). Oxford: Berg

Miller D (2001b) Possessions. In D Miller (ed) Home Possessions: Material culture behind closed doors (pp107-122). Oxford: Berg

Mitchell W and Green E (2002) “"I don't know what I'd do without our Mam": Motherhood, identity and support networks". The Sociological Review 50 (1): 1-22

North East Regional Information Partnership (2008) State of the Region Report 2008: North East England. Newcastle-upon-Tyne: NERIP http://www.nerip.com (last accessed 2 February 2009) 
North East Regional Information Partnership (2007) 2006 Annual Summary of Housing Market Activity and Dwelling Stock. Newcastle upon Tyne: NERIP http://www.nerip.com (last accessed 2 February 2009)

Phoenix A (1991) Young Mothers? Cambridge: Polity Press

Pawson H and Kintrea K (2002) Part of the problem or part of the solution: Social housing allocation policies and social exclusion in Britain. Journal of Social Policy 31 (4): $643-667$

Peel M (2003) The Lowest Rung: Voices of Australian Poverty. Cambridge: Cambridge University Press

Relph E (1976) Place and Placelessness. London: Pion

Robinson C (2002) "I think home is more than a building": young home(less) people on the cusp of home, self and something else. Urban Policy and Research 20 (1): 27 38

Robinson D with Coward S (2003) Your place, not mine: The experiences of homeless people staying with family and friends. London: Crisis

Rose G (2003) Family photographs and domestic spacings: a case study. Transactions 28: 5-18 
Sibley D (1995) Geographies of exclusion. London: Routledge

Stenning A (2008) For Working Class Geographies. Antipode 40(1) 9-14

Strangleman T (2008) Sociology, Social Class and New Working Class Studies. Antipode 40(1): 15-19

Tolia-Kelly D (2004a) Materializing post-colonial geographies: examining the textural landscapes of migration in the South Asian home. Geoforum 35: 675-88

Tolia-Kelly D (2004b) Locating processes of identification: studying the precipitates of re-memory through artefacts in the British Asian home. Transactions 29: 314-29

Valentine G (1993) (Hetero)sexing space: lesbian perceptions and experiences of everyday spaces. Environment and Planning D: Society and Space 11(4): 395-413

Varley A (2008) A place like this? Stories of dementia, home and self. Environment and Planning D: Society and Space 26: 47-67

Ureta S (2007) Domesticating homes: Material transformation and decoration among low-income families in Santiago, Chile. Home Cultures 4(3): 311-338

Wardhaugh J (1999) The unaccommodated woman: home, homelessness and identity. Sociological Review 47 (1): 91-109 
Watson R (2004) Risking it? Young mothers' experiences of motherhood and leisure. In W Mitchell, R Bunton and E Green (eds) Young people, risk and leisure (pp202223) Hampshire: Palgrave Macmillan

Watt P and Jacobs K (2000) Discourses of social exclusion: An analysis of Bringing Britain Together: A National Strategy for Neighbourhood Renewal. Housing Theory and Society 17 (1): 14-26

Wheelock J and Jones K (2002) 'Grandparents are the next best thing': Informal childcare for working parents in urban Britain. Social Policy 31: 441-463

Wheelock J and Oughton E (1996) The household as a focus for research. Journal of Economic Issues 30(1): 143-159

Wheelock J, Oughton E and Baines S (2003) Getting by with a little help from your family: Towards policy-relevant model of the household. Feminist Economics 9(1): $19-45$.

Whitzman C (2006) At the intersection of invisibilities: Canadian women, homelessness and health outside the 'big city'. Gender, place and Culture 13 (4):383399

Wills J (2008) Mapping class and its political possibilities. Antipode 40(1): 25-30 
Young I (1997) Intersecting voices: dilemmas of gender, political philosophy and policy. Princeton: Princeton University Press 


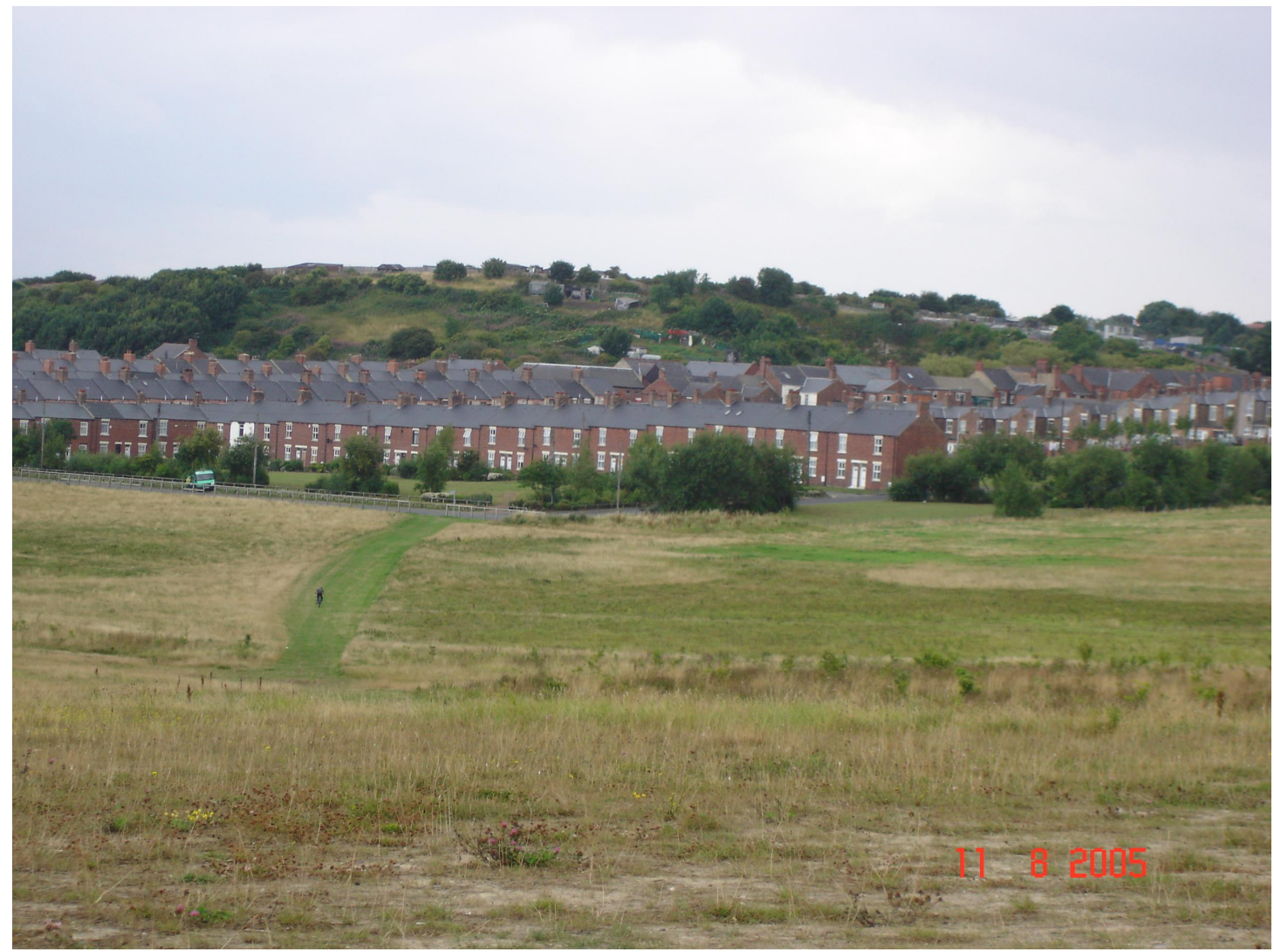

Figure 1: Easington colliery, taken from the former site of the colliery itself 


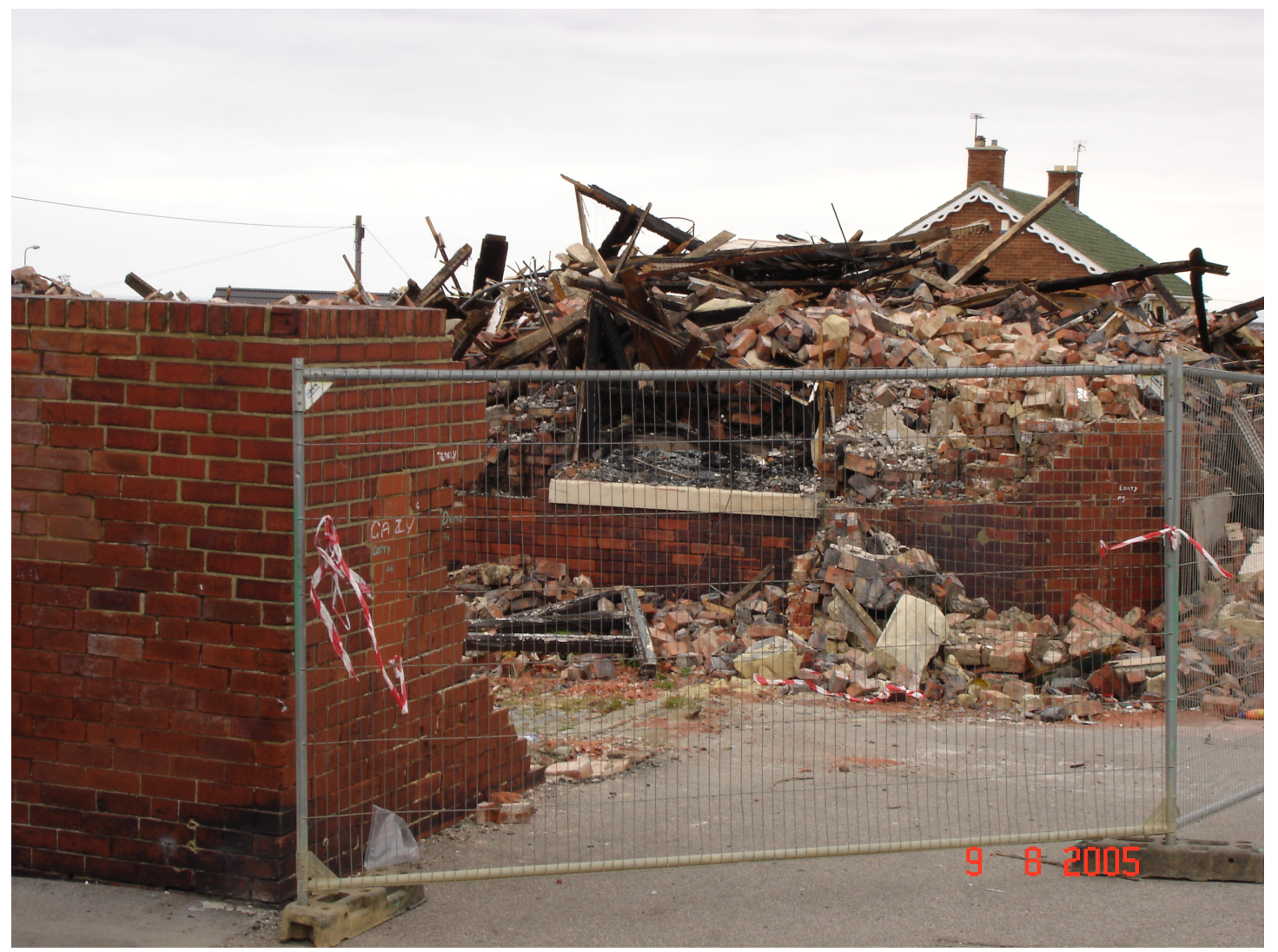

Figure 2: Demolition of housing in Easington Colliery, East Durham 


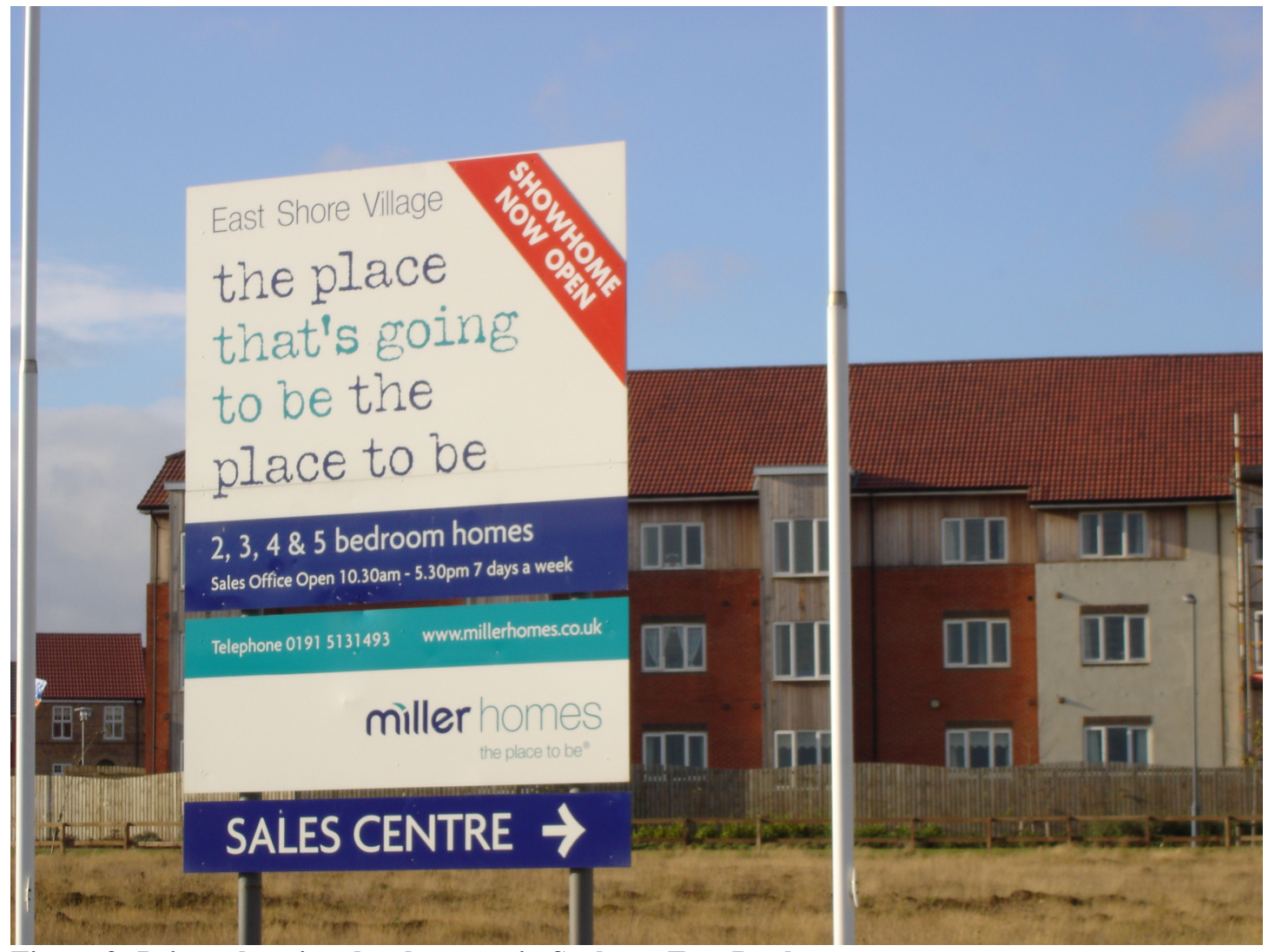

Figure 3: Private housing development in Seaham, East Durham 


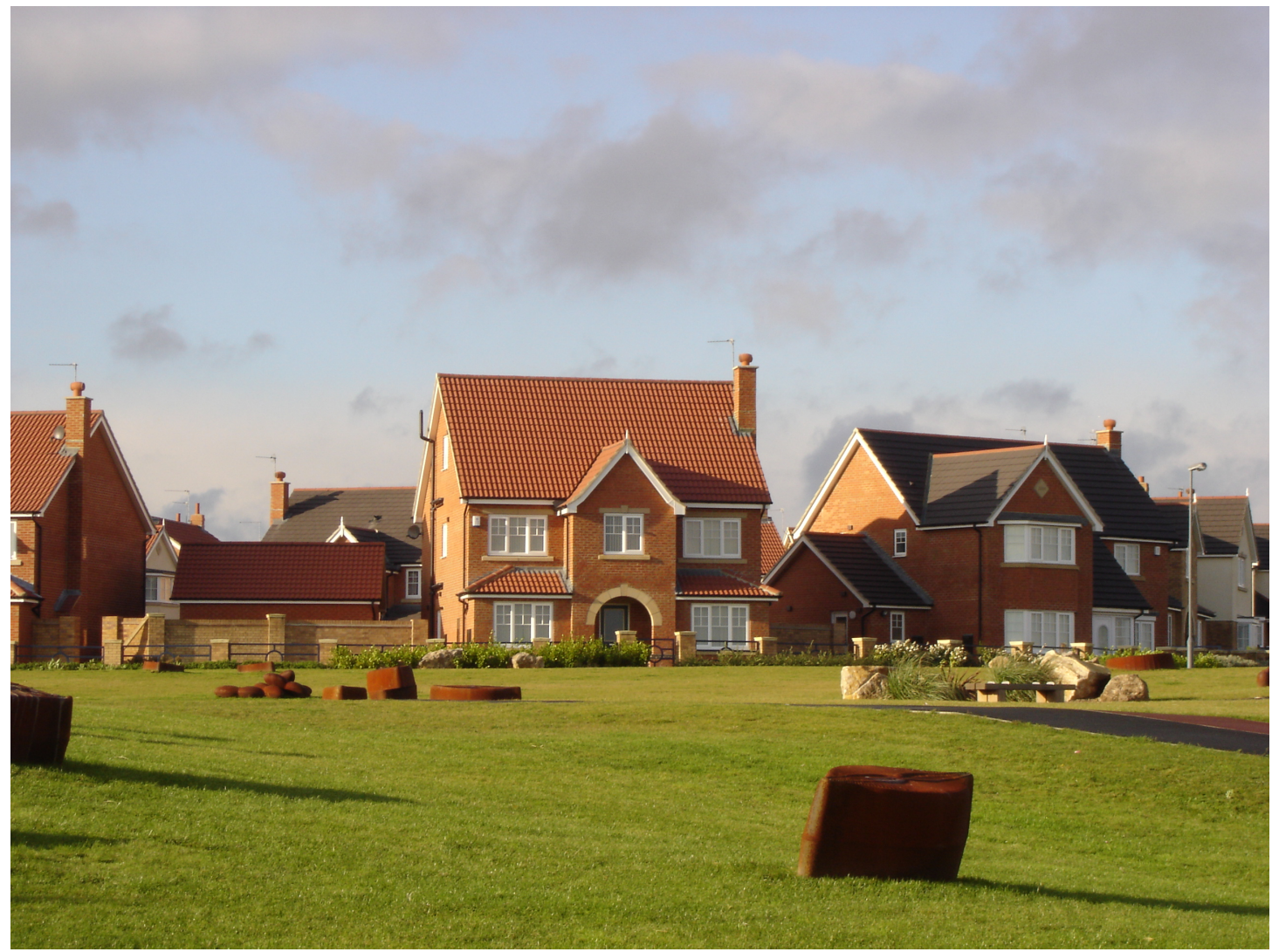

Figure 4: Housing development built on the site of a former colliery in Seaham, East Durham 
${ }^{\mathrm{i}}$ Since $1^{\text {st }}$ April 2009, Easington District Council has been replaced by Durham County Council, a unitary authority

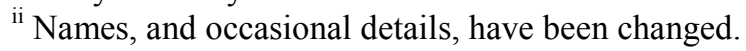

